\title{
Regulation of Hematopoietic Stem Cell Self-Renewal
}

\author{
TANNISHTha ReYA \\ Department of Pharmacology and Cancer Biology, Duke University Medical Center, Durham, \\ North Carolina 27710
}

\begin{abstract}
Every day, billions of new blood cells are produced in the body, each one derived from a hematopoietic stem cell (HSC). Because most mature blood stem cells have a limited life span, the ability of HSCs to perpetuate themselves through self-renewal and generate new blood cells for the lifetime of an organism is critical to sustaining life. A key problem in hematopoietic stem cell biology is how HSC self-renewal is regulated. Recent evidence suggests that signaling pathways classically involved in embryonic development - such as the Wnt signaling pathway — play an important role in regulating stem cell self-renewal. The Wnt signaling pathway has been shown to regulate stem cell fate choice in a variety of organs, including the skin, the nervous system, and the hematopoietic system. In the hematopoietic system, stimulation of hematopoietic progenitors and stem cells with soluble Wnt proteins or downstream activators of the Wnt signaling pathway leads to their expansion. Future studies focusing on the mechanism of action of the Wnt signaling pathway and its interaction with other pathways are needed to gain further insight into the regulation of stem cell self-renewal, not only in the hematopoietic system but also in a variety of other tissues.
\end{abstract}

\section{Isolation and Characterization of Hematopoietic Stem Cells}

Hematopoietic stem cells (HSCs) originally were identified functionally by Till and McCulloch (1961). A variety of methods have been used to isolate HSCs from the bone marrow, the primary site of hematopoiesis in the adult (Visser et al., 1984; Spangrude and Johnson, 1990; Goodell et al., 1996; Osawa et al., 1996; Adolfsson et al., 2001; Christensen and Weissman, 2001). One approach has been to utilize antibodies to a variety of HSC-associated cell surface molecules (e.g., c-kit, Sca-1, Thy1.1) and hematopoietic lineage markers such as B220, CD3, and Mac-1. Using this approach, all the HSC activity in the bone marrow has been found to reside within a small population of cells, characterized by their expression of low or undetectable levels of hematopoietic lineage markers $\left(\operatorname{lin}^{\mathrm{lo} /-}\right)$, high levels of c-kit and Sca-1, and low levels of Thy1.1 (lin ${ }^{\mathrm{lo} /}{ }^{-}$c-kit ${ }^{+}$Sca- $1^{+}$Thy $1.1^{\text {lo }}$ ) (Spangrude et al., 1988; Uchida and Weissman, 1992). Upon injection into lethally irradiated mice, these cells migrate to the appropriate microenvironments and undergo rapid expansion and differentiation. In the short term, they provide radioprotection, generating the erythroid and 
myeloid cells that are necessary for survival. Subsequently, they begin to self-renew and generate other hematopoietic cells (Figure 1) and can maintain steady-state hematopoiesis for the lifetime of the animal (Uchida and Weissman, 1992; Morrison and Weissman, 1994). The HSCs identified by such methods make up $0.05 \%$ of the total bone marrow. They have been separated further into two populations: one with long-term repopulating ability $\left(\mathrm{Lin}^{-} \mathrm{ckit}^{+} \mathrm{Sca}^{+} \mathrm{Thy} 1.1^{1 \mathrm{lo}}\right.$ cells, present at a frequency of 1:10,000 in the marrow) and the other with short-term repopulating ability $\left(\mathrm{Lin}^{\mathrm{lo}} \mathrm{Ckit}^{+} \mathrm{Sca}{ }^{+} \mathrm{Thy} 1.1^{\mathrm{lo}}\right.$ cells, present at a frequency of 1:2000 in the marrow). While both these populations can confer radioprotection, only the long-term-HSCs can provide reconstitution beyond 10 weeks (Morrison and Weissman, 1994).

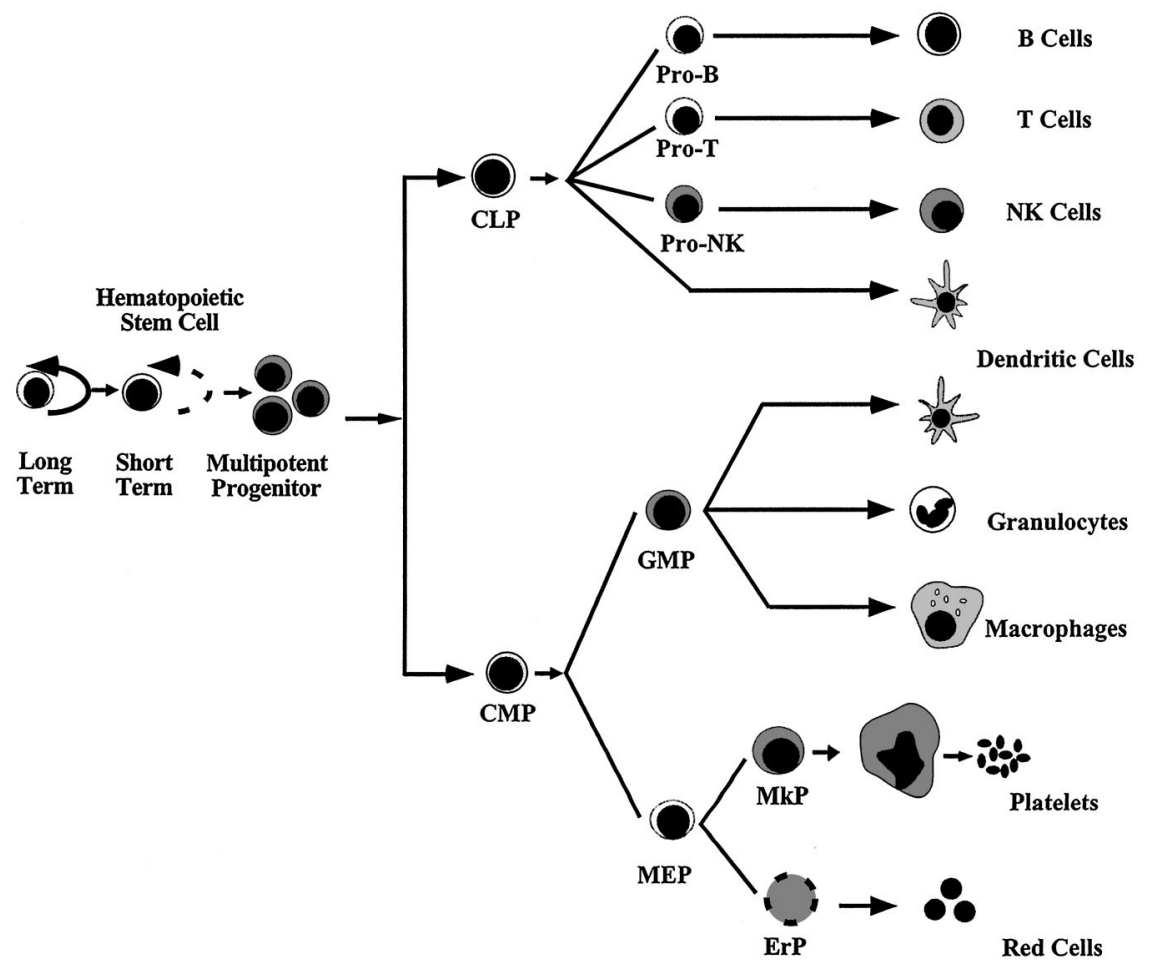

FIG. 1. Hematopoietic stem cell development. Hematopoietic stem cells can be classified into long-term, short-term, and multipotent progenitors, based on the extent of their self-renewal abilities. These cells go through a number of proliferative and commitment steps to give rise to all the myeloid and lymphoid lineages of the blood. Abbreviations: common lymphocyte progenitor (CLP); common myeloid progenitor (CMP); granulocyte monocyte progenitor (GMP); megakaryocyte erythrocyte progenitor (MEP). [Adapted from Reya T, Morrison SJ, Clarke MF, Weissman IL 2001 Stem cells, cancer, and cancer stem cells. Nature 414:105-111.] 


\section{Hematopoietic Stem Cell Self-Renewal}

While the phenotypic and functional properties of HSCs have been extensively characterized (for reviews, see Morrison et al., 1995; Weissman, 2000), a fundamental question that remains is how self-renewal is regulated. In most cases, combinations of growth factors that can induce extensive proliferation are unable to prevent differentiation of HSCs in long-term cultures. Although progress has been made in identifying conditions that maintain HSC activity in culture for a brief period of time (Miller and Eaves, 1997), it has proven exceedingly difficult to identify combinations of growth factors that cause significant expansion in culture in the number of progenitors with transplantable HSC activity.

Recent in vitro and in vivo studies investigating intracellular factors that mediate self-renewal have significantly advanced our understanding of HSC development. Ectopic expression of the transcription factor HoxB4 has been shown to be able to increase the numbers of transplantable hematopoietic stem cells both in vitro and in vivo (Sauvageau et al., 1995; Antonchuk et al., 2002). Alterations in HSC growth in transgenic and knockout mice also have identified potential mediators of HSC homeostasis in vivo. Mice that overexpress the antiapoptotic gene bcl-2 (Domen et al., 2000) have increased numbers of HSCs, suggesting that such antiapoptotic signals may contribute to regulating stem cell numbers. Mice lacking the G1 checkpoint regulator p21 display a higher rate of HSC proliferation and differentiation and a lower self-renewal capacity, suggesting that p21 is required for maintaining HSC quiescence and that, in its absence, HSCs rapidly proliferate and differentiate to more-committed lineages (Cheng et $a l ., 2000)$. While these are clearly important mediators of HSC development, the upstream signal that may control their activity remains unclear.

Signaling pathways classically studied in context of embryonic development - such as the Notch, Sonic hedgehog, and Wnt signaling pathways - have emerged as candidates for regulating self-renewal. The expression of constitutively active Notch1 in hematopoietic progenitors has been shown to lead to the establishment of at least some immortalized, cytokine-dependent cell lines that retain the potential to generate both lymphoid and myeloid cells in vitro and in long-term mouse reconstitution assays (Varnum-Finney et al., 2000). More recently, it was demonstrated that HSCs infected with Notch expand in vivo (Stier et al., 2002). While in many cases Notch1 expression in HSCs can lead to the rapid formation of T-cell leukemias in vivo, using RAG1-/- mice to prevent lymphocyte development allowed the effects on HSC expansion to be revealed in this study (Stier et al., 2002). Sonic hedgehog, another pathway studied classically as a regulator of embryonic development, also has emerged as a potential mediator of HSC development. Human cells highly enriched for hematopoietic progenitors $\left(\mathrm{CD} 34^{+} \mathrm{Lin}^{-} \mathrm{CD} 38^{-}\right)$exhibited increased self-renewal in response to 
Sonic hedgehog signaling in vitro, albeit in combination with a cocktail of six other growth factors (Bhardwaj et al., 2001). The fact that both Notch and Sonic hedgehog activation has been observed to inhibit the differentiation of progenitors in many different systems by acting to maintain progenitors in an undifferentiated state (Artavanis-Tsakonas et al., 1995; Harris et al., 1997; Rowitch et al., 1999; Wechsler-Reya and Scott, 1999) certainly supports the idea that these signals may promote self-renewal in a variety of tissues.

In an effort to identify novel signaling pathways that regulate stem cell self-renewal, we analyzed the transcription factor profile of mouse bone marrow HSCs. HSCs express high levels of GATA-2 and SCL, PU.1 (Akashi et al., 2000), and lymphoid enhancer factor-1 (LEF-1) (S.H. Cheshier, K. Li, I.L. Weissman, unpublished results). The expression of LEF-1, the transcriptional mediator of Wnt signaling, in HSCs and the expression of Wnts in the bone marrow (Reya et al., 2000), together with our previous findings that Wnt signaling regulates early B-cell growth (Reya et al., 2000), suggested that Wnts may control hematopoietic stem cell self-renewal.

\section{Wnt Signaling}

Wnt proteins represent a growing family of secreted signaling molecules that are expressed in diverse tissues and have been shown to influence multiple processes in vertebrate and invertebrate development (reviewed in Cadigan and Nusse, 1997). The founding member of the family, Int-1 (now called Wnt1), was identified as a protooncogene (Nusse and Varmus, 1982). Wnt proteins have been shown to regulate segment polarity in Drosophila (Siegfried and Perrimon, 1994) and axis specification in Xenopus (Moon et al., 1997). In the mouse, Wnt proteins are widely expressed. Mutations in Wnt genes result in defects in limb, somite, and axis formation and abnormal development of brain, kidney, and reproductive tract (Parr and McMahon, 1994; Monkley et al., 1996; Yoshikawa et al., 1997; Miller and Sassoon, 1998; Liu et al., 1999). In addition to its importance in normal development, dysregulation of the Wnt pathway can have potent oncogenic effects in tissues such as colon, breast, prostate, and skin (Tsukamoto et al., 1988; Korinek et al., 1997; Morin et al., 1997; Polakis, 2000).

Wnts act by binding to two types of receptor molecules at the surface of a cell (Figure 2). One is the Frizzled family of seven-pass transmembrane proteins, which contain a cysteine-rich extracellular domain that binds to Wnt proteins (Wodarz and Nusse, 1998). The second is a subset of the low-density lipoprotein receptor-related protein (or the LRP) family, specifically, LRP-5 and LRP-6 (called arrow in Drosophila) (Pinson et al., 2000; Tamai et al., 2000; Wehrli et al., 2000), a single-pass transmembrane protein. Experiments have provided evidence that both LRP-5/6 and Frizzled are needed to functionally activate the 


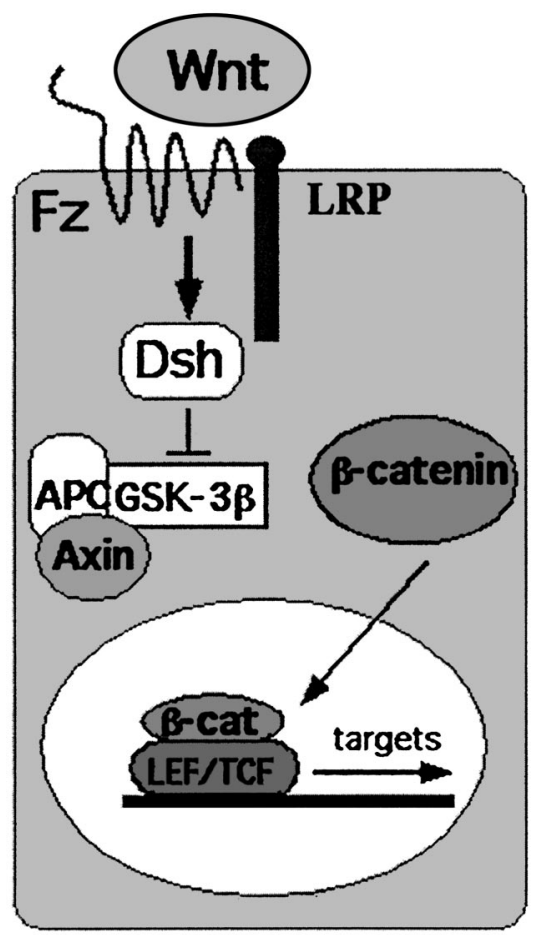

FIG. 2. Wnt signaling pathway. In the absence of Wnt signaling, the key regulator of the pathway, beta-catenin, is complexed with glycogen synthase kinase-3 beta (GSK-3 $\beta$ ), Axin, and adenomatosis polyposis coli (APC) as part of the destruction complex. This leads to the phosphorylation, ubiquitination, and degradation of $\beta$-catenin. The binding of Wnt to its coreceptors, Frizzled and LRP, leads to the dissociation of the destruction complex and stabilization of $\beta$-catenin, followed by its translocation to the nucleus and activation of target genes in collaboration with the LEF/TCF family of transcription factors.

downstream components of the canonical pathway (reviewed in Pandur and Kuhl, 2001).

In the absence of a Wnt signal, beta-catenin is associated with a large, multiprotein complex (the "destruction complex") that includes the scaffold protein Axin and the serine/threonine kinase, glycogen synthase kinase- 3 beta (GSK-3 $\beta$ ). In this complex, $\beta$-catenin is phosphorylated at its $\mathrm{NH}_{2}$ terminus by GSK- $3 \beta$ and thereby targeted for ubiquitination and degradation by proteosomes (Cadigan and Nusse, 1997). Axin is a key component of this complex, since it acts as a scaffold to significantly enhance the ability of GSK- $3 \beta$ to phosphorylate $\beta$-catenin. Binding of Wnt proteins to their receptors inhibits phosphorylation of $\beta$-catenin by GSK- $3 \beta$. This prevents $\beta$-catenin's degradation and results in 
stabilization and accumulation of $\beta$-catenin in the cytosol (Willert and Nusse, 1998). $\beta$-catenin then translocates to the nucleus, where it binds to members of the LEF/T-cell factor (TCF) family of transcription factors. LEF/TCF proteins normally are associated with the transcriptional repressor, Groucho (Cavallo et al., 1998; Roose et al., 1998), which suppresses their activity and represses gene transcription. Binding of $\beta$-catenin relieves this repression and allows LEF/TCF factors to induce expression of the appropriate target genes (reviewed in Eastman and Grosschedl, 1999).

\section{Wnt Signaling in Stem Cell and Progenitor Cell Development}

The possibility that the Wnt signaling pathway might contribute to the regulation of stem cell self-renewal in the hematopoietic system is supported by studies of nonhematopoietic progenitors and stem cells. For example, cultured human keratinocytes with higher proliferative potential have been shown to have increased levels of $\beta$-catenin, compared to those with lower proliferative capacity. Moreover, retroviral transduction of a constitutively activated form of $\beta$-catenin (mutated such that it cannot be degraded) results in increased selfrenewal of epidermal progenitors/stem cells (Zhu and Watt, 1999). Transgenic mice overexpressing activated $\beta$-catenin in epidermal stem cells develop hair follicle tumors (Gat et al., 1998). Moreover, the Wnt signaling pathway may be required in the maintenance or self-renewal of stem cells of the gut, based on the finding that TCF-4-deficient mice progressively exhaust the undifferentiated progenitors in the crypts of the gut epithelium during fetal development (Korinek et al., 1998). Finally, transgenic mice that overexpress activated $\beta$-catenin on a nestin promoter display increased cell-cycle entry of neural precursors and, consequently, a larger brain with characteristics of higher mammals (Chenn and Walsh, 2002).

Wnt signaling also has been implicated in the maintenance and renewal of committed precursors of a variety of lineages. Wnt10B has been shown to maintain preadipocytes in an undifferentiated state, while inhibition of Wnt signaling allows their differentiation into adipocytes (Ross et al., 2000). Moreover, we have shown that Wnt3A can induce proliferation of B-cell precursors in a LEF-1-dependent manner and that these precursors are depleted in LEF-1-deficient mice (Reya et al., 2000). Cumulatively, these findings suggest that the Wnt signaling pathway may regulate self-renewal of stem and progenitor cells in a variety of tissues (summarized in Table I). However, Wnt signaling also has been implicated in lineage commitment of stem cells, most notably, in the skin (Huelsken et al., 2001). Thus, its influence on self-renewal is likely to be context specific and does not preclude an ability to regulate lineage commitment as well. 
TABLE I

Summary of Selected Studies Demonstrating a Role for Wnt Signaling in Stem and Progenitor Cell Development from Diverse Mammalian Tissues

\begin{tabular}{|c|c|c|c|c|}
\hline Stimulus & Cell type & Effect & Assay & Reference \\
\hline $\begin{array}{l}\text { Activated } \beta- \\
\text { catenin }\end{array}$ & Keratinocytes & $\begin{array}{l}\text { Inhibition of } \\
\text { differentiation }\end{array}$ & In vitro & $\begin{array}{c}\text { Zhu et al. (1999) } \\
\text { Development } \\
\text { 126:2285 }\end{array}$ \\
\hline Wnt10B & Preadipocytes & $\begin{array}{l}\text { Inhibition of } \\
\text { differentiation }\end{array}$ & In vitro & $\begin{array}{l}\text { Ross et al. }(2000) \\
\text { Science } 289: 950\end{array}$ \\
\hline Wnt3A & $\begin{array}{l}\text { B-cell } \\
\text { progenitors }\end{array}$ & $\begin{array}{l}\text { Induction of } \\
\text { proliferation }\end{array}$ & In vitro & $\begin{array}{r}\text { Reya et al. (2000) } \\
\text { Immunity } 13: 15\end{array}$ \\
\hline Lef-1 knockout & $\begin{array}{l}\text { B-cell } \\
\text { progenitors }\end{array}$ & $\begin{array}{l}\text { Depletion of } \\
\text { progenitors }\end{array}$ & In vivo & $\begin{array}{r}\text { Reya et al. (2000) } \\
\text { Immunity } 13: 15\end{array}$ \\
\hline Tcf-4 knockout & $\begin{array}{l}\text { Intestinal stem } \\
\text { cells }\end{array}$ & $\begin{array}{l}\text { Depletion of stem } \\
\text { cells }\end{array}$ & In vivo & $\begin{array}{l}\text { Korinek et al. (1998) } \\
\text { Nat Genet 4:379 }\end{array}$ \\
\hline $\begin{array}{l}\text { Activated } \beta \text { - } \\
\text { catenin } \\
\text { transgenic }\end{array}$ & $\begin{array}{l}\text { Follicular } \\
\text { stem cells }\end{array}$ & $\begin{array}{l}\text { Hair follicle and } \\
\text { tumor formation }\end{array}$ & In vivo & $\begin{array}{l}\text { Gat et al. (1998) } \\
\text { Cell 95:605 }\end{array}$ \\
\hline $\begin{array}{l}\beta \text {-catenin } \\
\text { knockout }\end{array}$ & $\begin{array}{l}\text { Follicular } \\
\text { stem cells }\end{array}$ & Cell fate alteration & In vivo & $\begin{array}{l}\text { Huelsken et al. (2001) } \\
\quad \text { Cell 105:533 }\end{array}$ \\
\hline
\end{tabular}

\section{Wnt Signaling in Hematopoietic Stem Cell and Progenitor Cell Development}

While the Wnt pathway has been shown to play a critical role in the development of a variety of organs and lineages, relatively little is known about its function in the hematopoietic system. Recent evidence strongly suggests that Wnt signaling has an important regulatory role in hematopoietic progenitors/stem cells during both fetal and adult development.

During fetal hematopoiesis, Wnt proteins - specifically, Wnt5A and Wnt10B - are expressed in the yolk sac and the fetal liver, both sites of hematopoiesis in the embryo (Austin et al., 1997). Moreover, hematopoietic progenitor populations were found to express Wnt10B, suggesting that Wnts may be utilized in an autocrine manner. Conditioned media containing Wnt1, Wnt5A, or Wnt10B stimulated an 11-fold expansion of fetal liver progenitors in synergy with the stem cell growth factor, SLF (Austin et al., 1997). To determine whether the cells that proliferated as a consequence of Wnt stimulation in vitro maintained immature characteristics, cells were tested in semisolid colony-forming assays and found to have increased colony-forming ability, especially of blast cellcontaining colonies. This result suggested that treatment with Wnt proteins 
retained immature functional characteristics, at least as determined by in vitro assays. Consistent with the effects of soluble Wnt proteins in mouse hematopoiesis are their effects in human hematopoiesis (Van Den Berg et al., 1998). The exposure of $\mathrm{CD}_{34}{ }^{+} \mathrm{Lin}^{-}$human hematopoietic progenitors to Wnt5A, which was found to be expressed in these precursors, promoted the expansion of undifferentiated progenitors in the presence of stromal cells. The presence of undifferentiated progenitors was determined by in vitro colony-formation assays, which revealed a 10- to 20-fold higher number of colony-forming unit (CFU)-Mix colonies, which reflect the presence of an immature population. These in vitro experiments clearly point to an increase in immature progenitors in response to Wnt protein stimulation; however, further experiments with in vivo transplants will enable a better distinction between the expansion of hematopoietic progenitors and stem cells.

In contrast to these studies, some groups have reported that soluble Wnt proteins can inhibit self-renewal of hematopoietic progenitors. In an attempt to determine the role of Wnts in the context of the stromal cell microenvironment, one group (Yamane et al., 2001) utilized Wnt3A-conditioned media in Dexter cultures and noted a decrease in the numbers of $\mathrm{B}$ lineage and myeloid lineage cells. These data are difficult to interpret due to the complex nature of exposing both stromal elements and hematopoietic cells to Wnt3 A and the inability to distinguish direct and indirect effects. In a separate system using the quail mesodermal cell line QCE6 and avian whole-bone marrow, Wnt11 was shown to preferentially specify erythroid lineage fate in avian whole-bone marrow cultures (Brandon et al., 2000). While both these studies seem to indicate that Wnt proteins can influence lineage decisions, purified populations of stem cells will need to be tested in the context of purified Wnt proteins to make this conclusion definitively.

These studies (summarized in Table II) are difficult to compare directly due to the wide variation in the species used, the hematopoietic populations studied, the Wnt stimulus utilized, and the assays performed. The use of a highly purified, defined population of primary cells is critical to understanding the true nature of Wnt effects on HSCs, since an indirect effect through non-HSCs in a mixed population could confound interpretation of results. Moreover, due to the complexity of the Wnt pathway, it will be important to analyze the role of different components of the pathway to determine whether canonical Wnt signaling regulates HSC development. Finally, the use of a system in which the effects on HSCs can be assayed through both in vitro and in vivo approaches is critical to establishing the true effects of modulating Wnt signaling in HSCs. Many in vitro assays cannot distinguish between the activity of a fully uncommitted stem cell and an early committed progenitor cell (e.g., a common myeloid progenitor).

We have undertaken a set of experiments to identify methodically the role of Wnts in HSCs. We retrovirally transduced downstream components of the Wnt 
TABLE II

Summary of Selected Studies Demonstrating a Role for Wnt Signaling in Hematopoietic Stem and Progenitor Cell Development

\begin{tabular}{lccc}
\hline Stimulus & Cell type & Effect & Reference \\
\hline Wnt5A + SLF & Fetal liver & Increased & Austin et al. $(1997)$ \\
& enriched & progenitors & Blood 89:3624 \\
& precursors & & \\
Wnt5A + SLF + & Bone marrow & Increased & Van Den Berg et al. \\
feeder cells & enriched & progenitors & $(1998)$ Blood 92: \\
& precursors & & 3189 \\
Wnt3A + stromal & Bone marrow & Inhibition of & Yamane et al. $(2001)$ \\
cells & unenriched & hematopoiesis & J Immunol 167:765 \\
Wnt5A or & Bone marrow & Increased & Brandon et al. $(2000)$ \\
Wnt11A & nonadherent & differentiation & Blood 96:4132 \\
\hline
\end{tabular}

pathway into highly purified mouse bone marrow HSCs and analyzed their effects by in vitro and in vivo assays. Through this approach, we found that overexpression of activated $\beta$-catenin in long-term cultures of HSCs expands the pool of HSCs, as determined by both phenotype in vitro and ability to reconstitute the hematopoietic system in vivo (T. Reya, J. Domen, D. Scherer, A.W. Duncan, K. Willert, R. Nusse, H. Weissman, unpublished results). Activated $\beta$-catenin induced cells to enter the cell cycle and grow in long-term cultures for 1 to 4 weeks, while control HSCs did not survive beyond 48 hours (Table III). These expanded HSCs also retained the functional characteristics of HSCs, following transplant into allelically distinct irradiated mice. Moreover, ectopic expression of Axin, an inhibitor that acts by degrading $\beta$-catenin, led to inhibition of HSC proliferation, increased cell death of HSCs in vitro, and reduced reconstitution in vivo. These studies demonstrated the ability of downstream components of the Wnt pathway to regulate bone marrow HSC function. Moreover, using Wnt3A protein, we found that HSCs expand dramatically to soluble Wnt protein (up to 100 -fold), while maintaining the phenotypic characteristics of HSCs (K. Willert, J. Brown, E. Danenberg, R. Nusse, unpublished results). Cumulatively, our studies, together with those of others described here, indicate that Wnt signaling is important in the maintenance and self-renewal of hematopoietic stem and progenitor cells.

\section{Perspectives}

The studies that have examined the role of Wnt signaling in the hematopoietic stem and progenitor cell growth and cell-fate decisions indicate that the Wnt 
TABLE III

Summary of Studies Carried Out by Activating and Inhibiting Wnt Signaling in Purified HSC, by Using Retroviral Transduction of Downstream Mediators

\begin{tabular}{lll}
\hline & $\begin{array}{l}\text { Phenotype of cells } \\
\text { in vitro }\end{array}$ & $\begin{array}{l}\text { Transplantation ability } \\
\text { in vivo }\end{array}$ \\
\hline Control & +++ & +++ \\
Beta-catenin & ++++++ & ++++++ \\
Axin & + & + \\
\hline
\end{tabular}

[The relative extent of cell proliferation, while maintaining the surface phenotype of HSCs $\left(\mathrm{Lin}^{-1 \mathrm{lo}} \mathrm{c}-\mathrm{kit}^{+} \mathrm{sca}-1^{+} \mathrm{Thy} 1^{\mathrm{lo}}\right.$ ), and their ability to reconstitute the hematopoietic system of lethally irradiated recipient mice are indicated by the frequency of + signs.]

signaling pathway plays an important role in the hematopoietic system. These studies have raised many key questions about the mechanisms of HSC regulation. For example, in order to understand the mechanisms by which Wnt and $\beta$-catenin promote self-renewal, molecular analysis of the targets that are regulated in HSCs is needed. Moreover, given that multiple signaling pathways (e.g., Notch, Sonic hedgehog) and transcription factors (e.g., HoxB4) are emerging as regulators of HSC self-renewal, it will be important to determine if and how these signals are integrated to regulate HSC development. It is exciting to speculate that the Wnt, Notch, and Sonic hedgehog pathways may regulate similar targets genes in HSCs or may act in a hierarchical manner to regulate self-renewal. Answering these questions will enable us to understand the signals that regulate HSCs specifically and stem-cell growth in general. This will, in the long term, lead to the ability to create methods to maintain the undifferentiated state of hematopoietic stem cells in culture and have numerous practical ramifications for transplantation and regenerative therapies.

\section{ACKNOWLEDGMENTS}

The author would like to thank Andrew Duncan for help with the figures and tables and Jos Domen for helpful discussions. Some of the research mentioned in this review was supported in part by funds from the Cancer Research Institute and the Leukemia Research Foundation (awarded to TR).

\section{REFERENCES}

Adolfsson J, Borge OJ, Bryder D, Theilgaard-Monch K, Astrand-Grundstrom I, Sitnicka E, Sasaki Y, Jacobsen SE 2001 Upregulation of Flt3 expression within the bone marrow Lin(-)Sca1(+)c- kit(+) stem cell compartment is accompanied by loss of self-renewal capacity. Immunity 15:659-669

Akashi K, Traver D, Miyamoto T, Weissman IL 2000 A clonogenic common myeloid progenitor that gives rise to all myeloid lineages. Nature 404:193-197 
Antonchuk J, Sauvageau G, Humphries RK 2002 HOXB4-induced expansion of adult hematopoietic stem cells ex vivo. Cell 109:39-45

Artavanis-Tsakonas S, Matsuno K, Fortini ME 1995 Notch signaling. Science 268:225-232

Austin TW, Solar GP, Ziegler FC, Liem L, Matthews W 1997 A role for the Wnt gene family in hematopoiesis: expansion of multilineage progenitor cells. Blood 89:3624-3635

Bhardwaj G, Murdoch B, Wu D, Baker DP, Williams KP, Chadwick K, Ling LE, Karanu FN, Bhatia M 2001 Sonic hedgehog induces the proliferation of primitive human hematopoietic cells via BMP regulation. Nat Immunol 2:172-180

Brandon C, Eisenberg LM, Eisenberg CA 2000 WNT signaling modulates the diversification of hematopoietic cells. Blood 96:4132-4141

Cadigan KM, Nusse R 1997 Wnt signaling: a common theme in animal development, Genes Dev 11:3286-2305

Cavallo R, Cox R, Moline M, Roose J, Polevoy G, Clevers H, Peifer M, Bejsovec A 1998 Drosophila Tcf and Groucho interact to repress Wingless signalling activity. Nature 395: 604-608

Cheng T, Rodrigues N, Shen H, Yang Y, Dombkowski D, Sykes M, Scadden DT 2000 Hematopoietic stem cell quiescence maintained by p21cip1/waf1. Science 287:1804-1808

Chenn A, Walsh CA 2002 Regulation of cerebral cortical size by control of cell cycle exit in neural precursors. Science 297(5580):365-369

Christensen JL, Weissman IL 2001 Flk-2 is a marker in hematopoietic stem cell differentiation: a simple method to isolate long-term stem cells. Proc Natl Acad Sci USA 98:14541-14546

Domen J, Cheshier SH, Weissman IL 2000 The role of apoptosis in the regulation of hematopoietic stem cells: overexpression of Bcl-2 increases both their number and repopulation potential. J Exp Med 191:253-264

Eastman Q, Grosschedl R 1999 Regulation of LEF-1/TCF transcription factors by Wnt and other signals. Curr Opin Cell Biol 11:233-240

Gat U, DasGupta R, Degenstein L, Fuchs E 1998 De novo hair follicle morphogenesis and hair tumors in mice expressing a truncated beta-catenin in skin. Cell 95:605-614

Goodell MA, Brose K, Paradis G, Conner AS, Mulligan RC 1996 Isolation and functional properties of murine hematopoietic stem cells that are replicating in vivo. J Exp Med 183:1797-1806

Harris AW, Strasser A, Elefanty AG, Bath ML, Cory S 1997 Deregulation of cell survival in lymphomagenesis. Leukemia 11(suppl 3):383-384

Huelsken J, Vogel R, Erdmann B, Cotsarelis G, Birchmeier W 2001 beta-Catenin controls hair follicle morphogenesis and stem cell differentiation in the skin. Cell 105:533-545

Korinek V, Barker N, Morin PJ, van Wichen D, de Weger R, Kinzler KW, Vogelstein B, Clevers H 1997 Constitutive transcriptional activation by a beta-catenin-Tcf complex in APC -/- colon carcinoma. Science 275:1784-1787

Korinek V, Barker N, Moerer P, van Donselaar E, Huls G, Peters PJ, Clevers H 1998 Depletion of epithelia stem-cell compartments in the small intestine of mice lacking Tcf-4. Nat Genet 19:1-5

Liu P, Wakamiya M, Shea MJ, Albrecht U, Behringer RR, Bradley A 1999 Requirement for Wnt3 in vertebrate axis formation. Nat Genet 22:361-365

Miller C, Sassoon DA 1998 Wnt-7a maintains appropriate uterine patterning during the development of the mouse female reproductive tract. Development 125:3201-3211

Miller CL, Eaves CJ 1997 Expansion in vitro of adult murine hematopoietic stem cells with transplantable lympho-myeloid reconstituting ability. Proc Natl Acad Sci USA 94:1364813653

Monkley SJ, Delaney SJ, Pennisi DJ, Christiansen JH, Wainwright BJ 1996 Targeted disruption of the Wnt2 gene results in placentation defects. Development 122:3343-3353 
Moon RT, Brown JD, Torres M 1997 WNTs modulate cell fate and behavior during vertebrate development. Trends Genet 13:157-162

Morin PJ, Sparks AB, Korinek V, Barker N, Clevers H, Vogelstein B, Kinzler KW 1997 Activation of beta-catenin-Tcf signaling in colon cancer by mutations in beta-catenin or APC. Science 275:1787-1790

Morrison SJ, Weissman IL 1994 The long-term repopulating subset of hematopoietic stem cells is deterministic and isolatable by phenotype. Immunity 1:661-673

Morrison SJ, Uchida N, Weissman IL 1995 The biology of hematopoietic stem cells. Annu Rev Cell Dev Biol 11:35-71

Nusse R, Varmus HE 1982 Many tumors induced by the mouse mammary tumor virus contain a provirus integrated in the same region of the host genome. Cell 31:99-109

Osawa M, Hanada K, Hamada H, Nakauchi H 1996 Long-term lymphohematopoietic reconstitution by a single CD34- low/negative hematopoietic stem cell. Science 273:242-245

Pandur P, Kuhl M 2001 An arrow for wingless to take-off. Bioessays 23:207-210

Parr BA, McMahon AP 1994 Wnt genes and vertebrate development. Curr Opin Genet Dev 4:523-528

Pinson KI, Brennan J, Monkley S, Avery BJ, Skarnes WC 2000 An LDL-receptor-related protein mediates Wnt signalling in mice. Nature 407:535-538

Polakis P 2000 Wnt signaling and cancer. Genes Dev 14:1837-1851

Reya T, O'Riordan M, Okamura R, Devaney E, Willert K, Nusse R, Grosschedl R 2000 Wnt signaling regulates B lymphocyte proliferation through a LEF-1 dependent mechanism. Immunity 13:15-24

Reya T, Morrison SJ, Clarke MF, Weissman IL 2001 Stem cells, cancer, and cancer stem cells. Nature 414:105-111

Roose J, Molenaar M, Peterson J, Hurenkamp J, Brantjes H, Moerer P, van der Wetering M, Destree O, Clevers H 1998 The Xenopus Wnt effector XTcf3 interacts with Groucho-related transcriptional repressors. Nature 395:608-612

Ross SE, Hemati N, Longo KA, Bennett CN, Lucas PC, Erickson RL, MacDougald OA 2000 Inhibition of adipogenesis by Wnt signaling. Science 289:950-953

Rowitch DH, S-Jacques B, Lee SM, Flax JD, Snyder EY, McMahon AP 1999 Sonic hedgehog regulates proliferation and inhibits differentiation of CNS precursor cells. J Neurosci 19: $8954-8965$

Sauvageau G, Thorsteinsdottir U, Eaves CJ, Lawrence HJ, Largman C, Lansdorp PM, Humphries RK 1995 Overexpression of HOXB4 in hematopoietic cells causes the selective expansion of more primitive populations in vitro and in vivo. Genes Dev 9:1753-1765

Siegfried E, Perrimon N 1994 Drosophila wingless: a paradigm for the function and mechanism of Wnt signaling. Bioessays 16:395-404

Spangrude GJ, Johnson GR 1990 Resting and activated subsets of mouse multipotent hematopoietic stem cells. Proc Natl Acad Sci USA 87:7433-7437

Spangrude GJ, Heimfeld S, Weissman IL 1988 Purification and characterization of mouse hematopoietic stem cells [published erratum appears in Science 1989 244(4908):1030]. Science 241:58-62

Stier S, Cheng T, Dombkowski D, Carlesso N, Scadden DT 2002 Notch1 activation increases hematopoietic stem cell self-renewal in vivo and favors lymphoid over myeloid lineage outcome. Blood 99:2369-2378

Tamai K, Semenov M, Kato Y, Spokony R, Liu C, Katsuyama Y, Hess F, Saint-Jeannet JP, He X 2000 LDL-receptor-related proteins in Wnt signal transduction. Nature 407:530-535

Till JE, McCulloch EA 1961 A direct measurement of the radiation sensitivity of normal mouse bone marrow cells. Radiat Res 14:1419-1430 
Tsukamoto A, Grosschedl R, Guzman R, Parslow T, Varmus HE 1988 Expression of the int-1 gene in transgenic mice is associated with mammary gland hyperplasia and adenocarcinomas in male and female mice. Cell 55:619-625

Uchida N, Weissman IL 1992 Searching for hematopoietic stem cells: evidence that Thy-1.1lo LinSca- $1+$ cells are the only stem cells in C57BL/Ka-Thy-1.1 bone marrow. J Exp Med 175:175-184

Van Den Berg DJ, Sharma AK, Bruno E, Hoffman R 1998 Role of members of the Wnt gene family in human hematopoiesis. Blood 92:3189-3202

Varnum-Finney B, Xu L, Brashem-Stein C, Nourigat C, Flowers D, Bakkour S, Pear WS, Bernstein ID 2000 Pluripotent, cytokine-dependent, hematopoietic stem cells are immortalized by constitutive Notch1 signaling. Nat Med 6:1278-1281

Visser JWM, Gauman JGJ, Mulder AH, Eliason JF, de Leeuw AW 1984 Isolation of murine pluripotent hemopoietic stem cells. J Exp Med 59:1576-1590

Wechsler-Reya RJ, Scott MP 1999 Control of neuronal precursor proliferation in the cerebellum by Sonic Hedgehog. Neuron 22:103-114

Wehrli M, Dougan ST, Caldwell K, O'Keefe L, Schwartz S, Vaizel-Ohayon D, Schejter E, Tomlinson A, DiNardo S 2000 arrow encodes an LDL-receptor-related protein essential for Wingless signalling. Nature 407:527-530

Weissman IL 2000 Stem cells: units of development, units of regeneration, and units in evolution. Cell 100:157-168

Willert K, Nusse R 1998 b-catenin: a key mediator of Wnt signaling. Curr Opin Gen Dev 8:95-102

Wodarz A, Nusse R 1998 Mechanisms of Wnt signaling in development. Annu Rev Cell Dev Biol $14: 59-88$

Yamane T, Kunisada T, Tsukamoto H, Yamazaki H, Niwa H, Takada S, Hayashi SI 2001 Wnt signaling regulates hemopoiesis through stromal cells. J Immunol 167:765-772

Yoshikawa Y, Fujimori T, McMahon AP, Takada S 1997 Evidence that absence of Wnt-3a signaling promotes neuralization instead of paraxial mesoderm development in the mouse. Dev Biol 183:234-242

Zhu AJ, Watt FM 1999 beta-catenin signalling modulates proliferative potential of human epidermal keratinocytes independently of intercellular adhesion. Development 126:2285-2298 